\title{
Labor's Peace Time Responsibility Under the Norris-LaGuardia Act*
}

\author{
James McI. Henderson** \\ William H. Henderson****
}

\section{INTRODUCTION}

THE vesting in labor of powers, the exercising of which is certain to have a substantial effect upon the economic welfare of our free enterprise system, became a reality by the enactment of the NorrisLaGuardia Act ${ }^{1}$ and the pronouncements of the Supreme Court construing the Act. Whether or not these powers will have a beneficial or detrimental influence upon our economy depends upon the manner in which they are exercised. It is not the purpose of this article to predict the choice of labor or even to advocate a program. The article is confined to directing attention to these powers and indicating so far as can be now determined their scope with reference to the Antitrust laws. ${ }^{2}$ In order to fully present this, some brief mention is made of the background and growth of labor's climb to power leading up to the vesting of these responsibilities. This discussion, therefore, comprises two points, first, the growth of labor's power, and second, labor's powers under the Norris-LaGuardia Act in relation to the Antitrust laws.

\section{THE GROWTH OF LABOR'S POWER}

The organization of labor into unions for bargaining purposes with its incidental coercive activities of strikes and boycotts presented a clash of opposing principles under the common law without reference to the Antitrust laws. The courts, endeavoring to support the struggles of labor to better its economic position, evolved a compro-

* The opinions expressed herein are not necessarily those of the Department of Justice or its officials.

** Special Assistant to the Attorney General, Antitrust Division, Department of Justice, Chief, West Coast Offices, San Francisco, California, presently assigned to State Department on mission to Japan, (LL.B. George Washington University).

*** Special Attorney, Antitrust Division, Department of Justice, presently Acting Chief, West Coast Offices, San Francisco, California, ((LL.B. Stanford University).

147 Sint. (1932) 70, et seq., 29 U.S.C. $\$ \$ 101-115$ c.90.

2 The Antitrust laws referred to are the Sherman Act. 26 STAт. (1890) 209 as amended, 15 U.S.C. $\$ 1$, et. seq., Clayton Act, 38 STAT. (1914) 730 as amended, 15 U.S.C. $\S 12$, et. seq. 
mise of principles. Upon one hand was the principle that the conspiring of individuals in doing an act such as striking or boycotting, although lawful if done individually, was illegal if done jointly as a conspiracy. To offset this there was developed the principle that when a conspiracy had an object deemed justifiable, such a conspiracy was held permissible. There arose by the nature of the conflict of principles a myriad of distinctions involving the limits of such justification touching upon the questions of the primary and secondary boycotts and what was deemed the use of lawful and unlawful means. It is not intended to discuss these problems, and when purely intrastate transactions are involved, not affecting interstate commerce, such problems are the policy of each individual state. The effect of this conflict was felt, however, when the growth and development of labor activities were confronted by the mandate of the Antitrust laws. The general tendency to justify labor's activities had much to do with the fromulating of distinctions as to the applicability of such laws when the courts were faced with Antitrust actions directed at such activities. There was no room, of course, for the principle of justiflcation when the Antitrust laws were involved. The Antitrust laws are categorical in denouncements of restraints of trade. The only leeway from strict enforcement was the constitutional restriction that interstate commerce must be involved. It was early recognized that labor's activities in coercive bargaining contracts by strikes and boycotts affected interstate commerce. A distinction, particularly pertinent to such problems, and indeed it may be fairly said to be evolved from them, was formulated as a guidepost. The distinction went to the intent of the parties whose activities were claimed to affect interstate commerce. In order for such acts to come within the commerce clause of the Antitrust laws it was ruled that the acts, being indirect restraints upon commerce, must be the result of an intent to restrain commerce. ${ }^{3}$

Such distinctions became embarrassing to the courts when confronted with the problem of fixing a criterion for interstate commerce

3 United Mine Workers v. Coronado Coal Co. (1922) 259 U.S. 344; Coronado Coal Co. v. U.S. Mine Workers (1925) 268 U.S. 295; Packer Corporation v. State of Utah (1932) 285 U.S. 105; Blumenstock Bros. Adv. Agency v. Curtis Publishing Co. (1920) 252 U.S. 436; Industrial Assn. of San Francisco v. United States (1925) 268 U.S. 64 ; Bedford Cut Stone Company v. Journeyman Stonecutters' Assn. (1927) 274 U. S. 37 ; Local 167 v. United States (1934) 291 U.S. 293. This distinction was restated by the Supreme Court as late as May 2h, 1940, in Apex Hosiery Company v. Leader, 310 U.S. 469, although prior to that time the Court had, in passing upon the validity of other legislation of Congress, greatly enlarged its concept of the powers of Congress under the Commerce clause of the Constitution. 
decisions involving other legislation of Congress. ${ }^{4}$ The distinction was substantially weakened when the Supreme Court recognized that Congress in enacting the Sherman Antitrust Act intended to bestow under such Act its full constitutional authority so far as its commerce powers were concerned. ${ }^{5}$

Congress in its enactment of the Clayton Act in $1914^{\circ}$ attempted to alleviate hardships upon labor from strict enforcement of the Antitrust laws. However, despite the provisions of section 20 of that act, ${ }^{7}$ that none of the specified acts embraced by the Act should be held to be violations of any law of the United States, the courts construed the language as procedural, only, in preventing the issuance of injunctions involving or growing out of a labor dispute concerning terms and conditions of employment and as not to immunize labor from criminal responsibility under the Antitrust laws. ${ }^{8}$

\section{IABOR'S POWERS UNDER THE NORRIS-LAGUARDIA ACT}

IN RELATION TO THE ANTITRUST LAWS

It will be seen from the above discussion that assuming a vigorous enforcement of the Antitrust laws, the Clayton Act gave little substantial relief. It remained for the enactment of the Norris-LaGuardia Act to vest labor with substantial powers and immunization from the Antitrust laws as distinct from other elements of our free enterprise system. Curiously enough, however, there was no direct mandate to labor of such powers contained in the Norris-LaGuardia Act. The Act, although proclaiming the broad public policy of labor and its right to strike and providing, as did the Clayton Act, that no injunctive relief should issue, did not in so many words provide for immunity under the Antitrust laws. ${ }^{9}$

4 N.L.R.B. v. Jones \& Laughlin Stecl Corp. (1937) 301 U.S. 1; N.L.R.B. v. Fruehauf Trailer Co. (1937) 301 U.S. 49 ; N.L.R.B. v. Friedman-Harry Marks Clothing Co. (1937) 301 U.S. 58; Santa Cruz Fruit Packing Co. v. N.L.R.B. (1938) 303 U.S. 453 ; N.L.R.B. v. Fainblatt (1939) 306 U.S. 601 ; United States v. Rock Royal Cooperative, Inc. (1939) 307 U.S. 533 ; Currin v. Wallace (1939) 306 U.S. 1.

5 United States v. Frankfort Distilleries, Inc. (1945) 89 L.Ed. Adv. Dec. 649. The decision in the Frankfort case was foreshadowed by the Court's opinion in United States v. South-Eastern Underwriter's Association (1944) 322 U.S. 533, 558, where the Court states: "That Congress wanted to go to the utmost extent of its constitutional power in restraining trust and monopoly agrcements such as the indictment here charges admits of little, if any, doubt."

638 STAT. (1914) 730, c. 323,15 U.S.C. $\$ \$ 12-16$; 29 U.S.C. $\$ 52$.

7 Ibid.

8 Duplex Printing Press Co. v. Deering (1921) 254 U.S. 443; Bedford Cut Stone Co. v. Journeyman Stonecutters' Assn., supra note 3.

${ }^{9}$ The Norris-LaGuardia Act is containcd in 29 U.S.C. $\$ \$ 101-115$, inclusive. Sec- 
There was, therefore, a background of decisions under which the Supreme Court could have held, as it did in construing the Clayton Act, that the statute was procedural only and gave no immunity from criminal actions under the Antitrust laws. It was easily forseeable, however, in view of the more favorable policy towards labor, that these earlier decisions could furnish no accurate guide. What the interpretation of the Norris-LaGuardia Act would.be by the Supreme Court was a matter for open speculation.

The case of United States v. Hutcheson ${ }^{10}$ definitely confirmed the grant of immunity under the act, holding that criminal responsibility

tion 101 provides that no court shall issue any restraining order or temporary or permanent injunction, in a case involving or growing out of a labor dispute, nor that shall any such order he issued contrary to the puhlic policy declared in the Act. Section 102 declares the puhlic policy. It recites that the individual unorganized worker is commonly helpless to exercise freedom of contract in order to obtain "acceptable terms and conditions of employment." It recites the necessity that he shall have full freedom of association, self organization and designation of representatives of his own choosing "to negotiate the terms and conditions of his employment." Section 103 makes nonenforceable the so-called "yellow dog" agreements contained in employment contracts not to join a lahor union, and agreements that employment will terminate if the employee does join a union or employee organization. Section 104 enumerates specific acts not subject to restraining orders or injunctions. Included are casing or refusing to perform work, becoming or remaining a member of a labor organization, withholding employment benefits from a person participating or interested in a labor dispute, aiding by lawful means any person participating im or interested in a labor dispute, etc. This section provides that no court shall have jurisdiction to issue an injunction or restraining order to prohibit the above-mentioned actions "in any case involving or growing out of any labor dispute." Section 105 provides that the courts have no jurisdiction to issue injunctive relief upon the ground that the persons participating or interested in a labor dispute "constitute or are engaged in an unlawful combination or conspiracy enumerated in section 104." Section 106 provides that officers participating or. interested in a labor dispute shall not be responsible for the unlawful acts of individual members except upon clear proof of such. Section 107 provides that no injunctive relief shall be issued except after hearing and findings of unlawful acts and irreparable injury, and that the public officers were unwilling or unable to act. Section 108 provides that no injunctive relief in lahor disputes shall issue where obligations imposed by law have not been complied with, or that there las been failure to make reasonable efforts to settle the dispute by negotiation or Government machinery or arbitration. Section 109 provides there shall be no injunctive relief except on basis of finding of fact, and only covering acts expressly complained of and expressly included in the findings of fact. Section 110 provides for a circuit court of appeals review. Section 111 covers contempts. Section 112 covers contempts and demands for retirement of judge. Section 113 defines the terms used in the act. Sub-division (c) thereof provides "the term labor dispute mcludes any controversy concerning terms or conditions of employment, or concernimg the association or representation of persons negotiating, fixing, maintaining, changing or seeking to arrange terms or conditions of employment regardless of whether or not the disputants stand in the proximate relation of employer and employee."

10 (1940) 312 U.S. 219. 
could not lie when the acts complained came within the scope of the Norris-LaGuardia and Clayton Acts. It is interesting to note that the Supreme Court could find no language in the Norris-LaGuardia Act expressly granting such immunity. It was forced to fall back upon the language of section 20 of the Clayton Act providing that none of the conduct embraced within that act should be held violations of any law of the United States. Thus, to secure the immunity it believed contemplated by the Norris-LaGuardia Act, it harmonized the text of the Clayton Act with that of the Norris-LaGuardia Act, accepted the words of section 20 of the Clayton Act at their face value and repudiated its earlier decisions. ${ }^{11}$

The grant of immunity under the Norris-LaGuardia Act is not unlimited. Thus, by the terms of the Act, immunization applies only to controversies arising from labor disputes and concerning terms and conditions of employment, and this limitation is expressed in the Court's decisions. ${ }^{12}$ However, as to the limitation itself the Court has been extremely liberal, holding within the limitations, most of the demands of labor. There has been held immunized the demand of a labor union to be hired in lieu of members of a rival union; $;^{13}$ the demand that employers not use in their business musical records and transcriptions and the elimination of musical performance over the radio except that approved by the union, the Court reasoning this to be, in a sense, a demand for a closed shop; ${ }^{14}$ the demand that labor saving devices such as truck mixers of concrete not be used by employers in their business to the limitation of the number of employees to be hired ${ }^{15}$ the demand that employers not handle materials handled

11 The cases of Duplex Printing Press Co. v. Deering, supra note 8, and Bedford Cut Stone Co. v. Journeyman Stonecutters' Assn., supra note 3, interpreting the Clayton Act as granting procedural relief only, were expressly disapproved by the Supreme Court in the case of United States v. Hutcheson, supra note 10. The Court held that by the enactment of the Norris-LaGuardia Act, Congress had disapproved of the interpretation placed upon the Clayton Act by the Court in the cases of Duplex Printing Press v. Deering, supra note 8, and Bedford Cut Stone Co. v. Journeyman Stonecutters' Assn., supra note 3.

12 Columbia River Packers Assn. v. Hinton (1942) 315 U.S. 143; United States v. American Federation of Musicians (1943) 47 F. Supp. 304, Afd. 318 U.S. 741; American Medical Assn. v. Umited States (1942) 317 U. S. 519; See also United States v. Brims (1926) 272 U. S. 549, decided prior to the enactment of the Norris-LaGuardia Act.

13 United States v. Hutcheson, supra note 10.

14 United States v. American Federation of Musicians, supra note 12.

15 United States v. Carrozzo (1941) 37 F. Supp. 191, Afd. 
by members of rival unions; ${ }^{16}$ a demand that employers shall employ persons regardless of race; $;^{17}$ a demand that employers employ only members of the union that the union shall select, with the union refusing to admit the employers' employees to membership; ${ }^{18}$ a demand that dealers of milk unionize and cease to handle milk at cut rate prices; ${ }^{19}$ and a demand by labor that an employer require its employees to become members of a union. ${ }^{20}$

The principal limitation so far disclosed by the Supreme Court is that unions may not combine with employers in a conspiracy to restrain trade such as conspiring to bar from a state goods manufactured outside of its boundaries. This limitation was announced by the Supreme Court in the case of Allen Bradley v. Local Union No. $3^{21}$ and would seem to present at first blush a somewhat illogical distinction. It is clear that unions may under the immunity of the Norris-LaGuardia Act demand the non-use of nuachines that have their source outside of the state ${ }^{22}$ and it would seem to follow that an agreement between the union and the employer as a result of a victory by labor in a dispute would not be illegal. But under the theory of the decision of the Supreme Court in Allen Bradley v. Local Union No. 3, supra, a conspiracy between labor and employers to keep out of a state materials which labor would deem im aid of its objects is not countenanced. What distinction will eventually be made in these transactions is matter for speculation. It may be suggested that a distinction will be formulated, based on the intent of the parties. In the one case (where agreement is forced by reason of a labor dispute) such agreements will be valid, but on the other hand, (where agreement is predicated upon a conspiracy with employers to further the employers' own aims by restricted agreements of trade-that is, where the intent of the conspirators is to retard trade) such an agreement will not be immunized. This would be an analogy to the distinction originally drawn by the Suprene Court in determining whether labor activities imposed a restraint upon interstate commerce within the Antitrust

16 United States v. Building and Construction Trades Council of New Orleans (1941) 313 U.S. 539 (affirming District Court decision).

17 New Negro Alliance v. Sanitary Grocery Co. (1938) 303 U.S. 552.

18 Hunt v. Crumbock (1945) 89 L.Ėd. Adv. Op. 1429.

${ }^{10}$ Milk Wagon Drivers' Union v. Lake Valley Farm Products (1940) 311 U.S. 91.

20 Lauf v. E. G. Shinner \& Co. (1938) 303 U.S. 323.

21 (1945) 89 L.Ed. Adv. Op. 1441.

22 United States v. Carrozzo, supra note 15. 
laws. As has been pointed out above, the intent of the conspiring parties in such cases was controlling.

\section{CONCLUSION}

It will be readily seen from the above discussion that the power of labor embraces the right to influence to a great extent, the growth of industrial science and the development of labor-saving scientific advances in the realm of industry. It cannot be conceived that the exercise of this power for the stinting of growth and development could in the long run result to the benefit of labor. Basically the choice of policy is one of two alternatives. Shall our free enterprise system be a system emphasizing the utmost in production and scientific advancement or one emphasizing the limitation of the facilities of production? The primary goals of labor, increased wages, shorter working hours, etc., can only be attained in their greatest expression by the unfettered development and growth of science and industry rather than by a nearsighted approach that might induce the suppression of production. Nor is labor alone concerned in the choice. The whole economy of the nation is involved. A free enterprise system competing as it must with economic systems of other types of government, it would seem, would best thrive if it may act without controls that would delay or obstruct progress in industrial development. The powers of labor exercised under the motive of far-reaching purpose must have a profound effect on our progress. As was expressed by President Harry S. Truman in his speech of October 30,1945, on wage-price policy:

"Labor itself has a responsibility to aid industry in reaching this goal of higher production and more jobs. It must strive constantly for greater efficiency and greater productivity-good work done, for good wages earned. Only in that way can we reach the mass production that has brought this country to the front of the industrial countries of the world." 